\title{
A LEI DE IMPROBIDADE E OS AGENTES PÚBLICOS
}

THE IMPROBITY LAW AND THE PUBLIC AGENTS

Marina Yamashita BALDUINO1

ISSUE DOI: $10.21207 / 1983.4225 .365$

\section{RESUMO}

A Improbidade Administrativa tem sido um tema de alta relevância no contexto da Administração Pública atual. Em observância ao comando constitucional previsto no $\S 4 .^{\circ}$ do artigo 37 da Constituição Federal o qual pune o agente ímprobo, surgiu a Lei de Improbidade Administrativa - Lei n. ${ }^{\circ} 8.429$ de 02 de junho de 1992. Este trabalho visa estudar a referida lei e sua aplicabilidade em relação aos agentes públicos.

Palavras-chave: lei de improbidade administrativa; Administração Pública; agentes públicos; probidade; Constituição Federal; legalidade.

${ }^{1}$ Graduada (2015) em Ciências Contábeis pelo Centro Universitário de Franca (UNIFACEF) e em Direito pela Faculdade de Direito de Franca (FDF). E-mail: marinamuri1lo20@gmail.com 


\section{INTRODUÇÃO}

Como se sabe, o princípio constitucional da moralidade administrativa encontra-se presente em nosso ordenamento jurídico desde a promulgação da Constituição Federal de 1988 no caput de seu artigo 37.

Com isso, passou-se a exigir dos agentes públicos não só a observância da legalidade (outro importante princípio constitucional) perante a Administração Pública, mas também a observância dos preceitos morais e éticos na condução da coisa pública.

A partir disso, os atos que atentassem contra a moralidade administrativa também passaram a ser reconhecidos como lesivos à administração pública, motivo pelo qual a Constituição Federal de 1988, em seu art. $37, \S 4$. $^{\circ}$, estabeleceu sanções aos agentes públicos que agissem com improbidade no trato da administração pública.

Nesse contexto, ocorreu a publicação da Lei $n^{\circ}$. 8.429/92, também conhecida como Lei de Improbidade Administrativa (LIA), definindo os atos que importam improbidade administrativa, bem como regulando um importante instrumento de controle da moralidade administrativa e de responsabilização civil, política e administrativa do agente ímprobo, qual seja, a ação civil por improbidade administrativa.

O presente trabalho tem como finalidade estudar a lei de improbidade e analisar sua aplicabilidade em face dos agentes políticos, baseando-se na pesquisa dos entendimentos doutrinários e jurisprudenciais em torno do tema, com vistas a analisar a natureza jurídica do referido diploma legal.

Será, para tanto, analisada a jurisprudência formada sobre o tema.

Ao final, concluir-se-á que a Lei de Improbidade Administrativa é aplicável aos agentes políticos, não havendo qualquer relação de exclusão entre aquele diploma legal e o regime dos crimes de responsabilidade.

\section{A LEI 8429/92 E OS AGENTES PÚBLICOS - CONCEITO DE IMPROBIDADE}

Improbidade é "palavra latina oriunda de improbidate, significando falta de probidade, desonestidade", conforme nos ensina Waldo Fazzio Júnior (2001, p. 130). 
De acordo com José Afonso da Silva (2001, p. 653), improbidade é: "uma imoralidade administrativa qualificada pelo dano ao erário e correspondente vantagem ao ímprobo ou a outrem."

Para a professora administrativista, Maria Sylvia Zanella di Pietro, (2007, p. 709) improbidade é sinônimo de moralidade, assim o agente ímprobo é aquele que se qualifica como violador do princípio da moralidade. Tal pensamento é comum também a José dos Santos Carvalho Filho (2009, p. 984) e a Marcelo Figueiredo (2003, p. 23-24).

José Afonso da Silva (2001. p. 653), por sua vez, conceitua improbidade administrativa como "uma imoralidade administrativa qualificada pelo dano ao erário e correspondente vantagem ao ímprobo ou a outrem." probidade:

Segundo Fabrício José Cavalcante (2009, p. 37), ao definir im-

Por certo se deve entender o vocabulário improbidade como antônimo da palavra probidade, o qual é diretamente ligado à ética, a moral, a honestidade, aos bons costumes e à justiça. A moralidade é princípio constitucionalmente estabelecido na Carta Magna da República Federativa do Brasil de 1988.

No mesmo sentido, Fernando da Fonseca Gajardoni et al. (2012, p. 35) mencionam que:

A improbidade administrativa constitui uma violação ao princípio constitucional da moralidade, princípio basilar da Administração Pública, estabelecido no caput do art. 37 da CF. Assim, a improbidade pode ser classificada como uma imoralidade administrativa qualificada, na medida em que somente as condutas tipificadas nos arts. 9., 10 e 11 da LIA podem ser consideradas atos de improbidade administrativa.

Com efeito, corrobora ainda, Fábio Medina Osório (apud GAJARDONI et al., 2012. p. 37):

Improbidade é conceito jurídico indeterminado vazado em cláusulas gerais, que exige, portanto, esforço de sistematização e concreção por parte do intérprete. 
Reveste-se de ilicitude acentuadamente grave e exige - o ato ímprobo - requisitos de tipicidade objetiva e subjetiva, acentuadamente o dolo (nos casos de enriquecimento ilícito e prática atentatória aos princípios) e a culpa grave (nos casos de lesão ao erário).

Acrescenta Hely Lopes Meirelles (2002, p. 108):

O dever de probidade está constitucionalmente integrado na conduta do administrador público como elemento necessário à legitimidade de seus atos. $\mathrm{O}$ velho e esquecido conceito romano do probus e do improbus administrador público está presente na nossa legislação administrativa, como também na Constituição da República, que pune a improbidade na Administração com sanções políticas, administrativas e penais.

Neste sentido, improbidade administrativa não é sinônimo de ilícito penal nem se confunde com falta disciplinar a que se sujeitam os servidores públicos, tampouco merecendo ser classificada como ilícito civil.

Para conhecer-se, de fato, a improbidade administrativa é necessário que conheçamos os princípios norteadores da Administração Pública que se encontram, principalmente, no artigo 37, caput, da Constituição Federal, quais sejam: Princípio da Legalidade, Princípio da Impessoalidade, Princípio da Moralidade, Princípio da Publicidade e Princípio da Eficiência. A inobservância a estes princípios é o que caracteriza os atos ímprobos.

Assim, improbidade, em linhas gerais, é a falta de observância aos princípios citados quando do exercício de função, mandato, cargo ou emprego público.

Incluída pela Constituição da República Federativa do Brasil de 1988 como princípio fundamental da Administração Pública, a probidade administrativa é o âmago do princípio da moralidade administrativa. Considera-se que a moralidade administrativa, quando vista em conjunto com os demais princípios que regem a Administração Pública, é guia que atua dentro da lei, condicionando o exercício da discricionariedade do agente público e regulando sua ação aos fins legais, à boa-fé, à razoabilidade, à proporcionalidade e à isonomia.

Deste modo, o princípio da moralidade tem imensa relevância para o controle dos atos da Administração, visto que é no mau uso das 
competências discricionárias que estão situadas as mais gravosas lesões ao Estado de Direito. missivos.

Os atos que ensejam a improbidade podem ser omissivos ou co-

A Lei de Improbidade (Lei n. ${ }^{\circ}$ 8.429/92) apresenta três efeitos aos atos ímprobos que são: atos que importam enriquecimento ilícito (artigo $90^{\circ}$ da referida lei); atos que geram dano ao erário (artigo 10) e atos que atentem contra os princípios da administração (artigo 11).

As modalidades acima citadas podem ocorrer de forma singular ou conjunta, caso em que se formam relações complexas de improbidade.

Por fim, cumpre ressaltar a importância da observância do elemento subjetivo, conforme nos ensina Licínia Rossi, (2015), a conduta vez que o legislador se preocupou em distinguir os atos dolosos daqueles culposos. Assim, pode-se dizer que: para configuração de enriquecimento ilícito (artigo 9..$^{\circ}$ ) é necessário dolo na conduta do agente assim como no caso de atentado aos princípios (artigo 11), ou seja, analisa-se a vontade de realizar ato que atente contra os princípios da administração.

São considerados atos que geram enriquecimento ilícito:

I - receber, para si ou para outrem, dinheiro, bem móvel ou imóvel, ou qualquer outra vantagem econômica, direta ou indireta, a título de comissão, percentagem, gratificação ou presente de quem tenha interesse, direto ou indireto, que possa ser atingido ou amparado por ação ou omissão decorrente das atribuições do agente público;

II - perceber vantagem econômica, direta ou indireta, para facilitar a aquisição, permuta ou locação de bem móvel ou imóvel, ou a contratação de serviços pelas entidades referidas no art. $1^{\circ}$ por preço superior ao valor de mercado;

III - perceber vantagem econômica, direta ou indireta, para facilitar a alienação, permuta ou locação de bem público ou o fornecimento de serviço por ente estatal por preço inferior ao valor de mercado;

IV - utilizar, em obra ou serviço particular, veículos, máquinas, equipamentos ou material de qualquer 
natureza, de propriedade ou à disposição de qualquer das entidades mencionadas no art. $1^{\circ}$ desta lei, bem como o trabalho de servidores públicos, empregados ou terceiros contratados por essas entidades;

V - receber vantagem econômica de qualquer natureza, direta ou indireta, para tolerar a exploração ou a prática de jogos de azar, de lenocínio, de narcotráfico, de contrabando, de usura ou de qualquer outra atividade ilícita, ou aceitar promessa de tal vantagem;

VI - receber vantagem econômica de qualquer natureza, direta ou indireta, para fazer declaração falsa sobre medição ou avaliação em obras públicas ou qualquer outro serviço, ou sobre quantidade, peso, medida, qualidade ou característica de mercadorias ou bens fornecidos a qualquer das entidades mencionadas no art. $1^{\circ}$ desta lei;

VII - adquirir, para si ou para outrem, no exercício de mandato, cargo, emprego ou função pública, bens de qualquer natureza cujo valor seja desproporcional à evolução do patrimônio ou à renda do agente público;

VIII - aceitar emprego, comissão ou exercer atividade de consultoria ou assessoramento para pessoa física ou jurídica que tenha interesse suscetível de ser atingido ou amparado por ação ou omissão decorrente das atribuições do agente público, durante a atividade;

IX - perceber vantagem econômica para intermediar a liberação ou aplicação de verba pública de qualquer natureza;

$\mathrm{X}$ - receber vantagem econômica de qualquer natureza, direta ou indiretamente, para omitir ato de ofício, providência ou declaração a que esteja obrigado;

XI - incorporar, por qualquer forma, ao seu patrimônio bens, rendas, verbas ou valores integrantes do acervo patrimonial das entidades mencionadas no art. $1^{\circ}$ desta lei; 
XII - usar, em proveito próprio, bens, rendas, verbas ou valores integrantes do acervo patrimonial das entidades mencionadas no art. $1^{\circ}$ desta lei.

Por outro lado, nos casos de dano ao erário (artigo 10) basta a culpa, ou seja, basta a atuação com negligência, imprudência ou imperícia. Os atos que ensejam dano ao erário são:

I - facilitar ou concorrer por qualquer forma para a incorporação ao patrimônio particular, de pessoa física ou jurídica, de bens, rendas, verbas ou valores integrantes do acervo patrimonial das entidades mencionadas no art. $1^{\circ}$ desta lei;

II - permitir ou concorrer para que pessoa física ou jurídica privada utilize bens, rendas, verbas ou valores integrantes do acervo patrimonial das entidades mencionadas no art. $1^{\circ}$ desta lei, sem a observância das formalidades legais ou regulamentares aplicáveis à espécie;

III - doar à pessoa física ou jurídica bem como ao ente despersonalizado, ainda que de fins educativos ou assistências, bens, rendas, verbas ou valores do patrimônio de qualquer das entidades mencionadas no art. $1^{\circ}$ desta lei, sem observância das formalidades legais e regulamentares aplicáveis à espécie;

IV - permitir ou facilitar a alienação, permuta ou locação de bem integrante do patrimônio de qualquer das entidades referidas no art. $1^{\circ}$ desta lei, ou ainda a prestação de serviço por parte delas, por preço inferior ao de mercado;

V - permitir ou facilitar a aquisição, permuta ou locação de bem ou serviço por preço superior ao de mercado;

VI - realizar operação financeira sem observância das normas legais e regulamentares ou aceitar garantia insuficiente ou inidônea; 
VII - conceder benefício administrativo ou fiscal sem a observância das formalidades legais ou regulamentares aplicáveis à espécie;

VIII - frustrar a licitude de processo licitatório ou de processo seletivo para celebração de parcerias com entidades sem fins lucrativos, ou dispensá-los indevidamente;

IX - ordenar ou permitir a realização de despesas não autorizadas em lei ou regulamento;

$\mathrm{X}$ - agir negligentemente na arrecadação de tributo ou renda, bem como no que diz respeito à conservação do patrimônio público;

XI - liberar verba pública sem a estrita observância das normas pertinentes ou influir de qualquer forma para a sua aplicação irregular;

XII - permitir, facilitar ou concorrer para que terceiro se enriqueça ilicitamente;

XIII - permitir que se utilize, em obra ou serviço particular, veículos, máquinas, equipamentos ou material de qualquer natureza, de propriedade ou à disposição de qualquer das entidades mencionadas no art. $1^{\circ}$ desta lei, bem como o trabalho de servidor público, empregados ou terceiros contratados por essas entidades.

XIV - celebrar contrato ou outro instrumento que tenha por objeto a prestação de serviços públicos por meio da gestão associada sem observar as formalidades previstas na lei;

XV - celebrar contrato de rateio de consórcio público sem suficiente e prévia dotação orçamentária, ou sem observar as formalidades previstas na lei.

XVI - facilitar ou concorrer, por qualquer forma, para a incorporação, ao patrimônio particular de pessoa física ou jurídica, de bens, rendas, verbas ou valores 
públicos transferidos pela administração pública a entidades privadas mediante celebração de parcerias, sem a observância das formalidades legais ou regulamentares aplicáveis à espécie;

XVII - permitir ou concorrer para que pessoa física ou jurídica privada utilize bens, rendas, verbas ou valores públicos transferidos pela administração pública a entidade privada mediante celebração de parcerias, sem a observância das formalidades legais ou regulamentares aplicáveis à espécie;

XVIII - celebrar parcerias da administração pública com entidades privadas sem a observância das formalidades legais ou regulamentares aplicáveis à espécie;

XIX - agir negligentemente na celebração, fiscalização e análise das prestações de contas de parcerias firmadas pela administração pública com entidades privadas;

XX - liberar recursos de parcerias firmadas pela administração pública com entidades privadas sem a estrita observância das normas pertinentes ou influir de qualquer forma para a sua aplicação irregular.XXI liberar recursos de parcerias firmadas pela administração pública com entidades privadas sem a estrita observância das normas pertinentes ou influir de qualquer forma para a sua aplicação irregular.

De acordo com o ministro Napoleão Nunes Maia Filho, no informativo 40 do STJ, (julgado em 24/4/2014) "ainda que demonstrada grave culpa, se não evidenciado o dolo específico de lesar os cofres públicos ou de obter vantagem indevida, bens tutelados pela lei 8429/92 não se configuram improbidade administrativa".

Para concluir, cabem algumas apresentações gráficas com o intuito de tornar mais esclarecedor o tema:

\begin{tabular}{|l|l|l|}
\hline $\begin{array}{l}\text { Enriquecimento ilí- } \\
\text { cito }\end{array}$ & Dano ao erário & $\begin{array}{l}\text { Violação aos princí- } \\
\text { pios }\end{array}$ \\
\hline
\end{tabular}




\begin{tabular}{|l|l|l|}
\hline Artigo 9. ${ }^{\circ}$ da LIA & Artigo 10 da LIA & Artigo 11 da LIA \\
\hline $\begin{array}{l}\text { Sanções: artigo 12, I, } \\
\text { da LIA }\end{array}$ & $\begin{array}{l}\text { Sanções: artigo 12, II, } \\
\text { da LIA }\end{array}$ & $\begin{array}{l}\text { Sanções: artigo 12, } \\
\text { III, da LIA }\end{array}$ \\
\hline $\begin{array}{l}\text { Elemento subjetivo: } \\
\text { dolo/má-fé }\end{array}$ & $\begin{array}{l}\text { Elemento subjetivo: } \\
\text { culpa/dolo }\end{array}$ & $\begin{array}{l}\text { Elemento subjetivo: } \\
\text { dolo/má-fé }\end{array}$ \\
\hline
\end{tabular}

(Rossi, 2015)

Pertinente também a representação gráfica, ainda que de forma resumida, do professor Alexandre Mazza (2015, p. 655-656) acerca do tema:

\begin{tabular}{|c|c|c|c|}
\hline & $\begin{array}{l}\text { Atos de impro- } \\
\text { bidade que cau- } \\
\text { sam enriqueci- } \\
\text { mento ilícito do } \\
\text { agente }\end{array}$ & $\begin{array}{l}\text { Atos de impro- } \\
\text { bidade que cau- } \\
\text { sam prejuízo ao } \\
\text { erário }\end{array}$ & $\begin{array}{l}\text { Atos de impro- } \\
\text { bidade que aten- } \\
\text { tam contra os } \\
\text { princípios da } \\
\text { administração } \\
\text { pública }\end{array}$ \\
\hline Previsão legal & $\begin{array}{l}\text { Artigo } 9 .^{\circ} \mathrm{da} \\
\text { LIA }\end{array}$ & $\begin{array}{l}\text { Artigo } 10 \text { da } \\
\text { LIA }\end{array}$ & $\begin{array}{l}\text { Artigo } 11 \text { da } \\
\text { LIA }\end{array}$ \\
\hline Características & $\begin{array}{l}\text { Produzem uma } \\
\text { vantagem patri- } \\
\text { monial indevida } \\
\text { para o agente }\end{array}$ & $\begin{array}{l}\text { Ensejam perda } \\
\text { patrimonial, } \\
\text { desvio, apropri- } \\
\text { ação, malbara- } \\
\text { tamento ou dila- } \\
\text { pidação dos } \\
\text { bens públicos }\end{array}$ & $\begin{array}{l}\text { Não causam } \\
\text { prejuízo ao erá- } \\
\text { rio, mas desa- } \\
\text { tentam deveres } \\
\text { de honestidade, } \\
\text { imparcialidade, } \\
\text { legalidade e le- } \\
\text { aldade às insti- } \\
\text { tuições }\end{array}$ \\
\hline Tipo de conduta & Dolosa & $\begin{array}{l}\text { Dolosa ou cul- } \\
\text { posa }\end{array}$ & Dolosa \\
\hline Exemplo & $\begin{array}{l}\text { Receber di- } \\
\text { nheiro, gratifi- } \\
\text { cação ou pre- } \\
\text { sente no exercí- } \\
\text { cio da função } \\
\text { pública }\end{array}$ & $\begin{array}{l}\text { Permitir que ter- } \\
\text { ceiro utilize, em } \\
\text { proveito pró- } \\
\text { prio, verbas ou } \\
\text { bens do serviço } \\
\text { público }\end{array}$ & $\begin{array}{l}\text { Negar publici- } \\
\text { dade aos atos } \\
\text { oficiais }\end{array}$ \\
\hline
\end{tabular}




\section{FUNDAMENTO CONSTITUCIONAL DA LIA}

A base constitucional que "sustenta" a punição dos atos de improbidade é o artigo 37. §4. ${ }^{\circ}$ o qual diz que: "Os atos de improbidade administrativa importarão a suspensão dos direitos políticos, a perda da função pública, a indisponibilidade dos bens e o ressarcimento ao erário, na forma e gradação previstas em lei, sem prejuízo da ação penal cabível."

Assim, entende-se ser a norma acima de eficácia limitada, ou seja, o texto constitucional apenas ganhou alcance prático com a promulgação da Lei de Improbidade Administrativa em 1992.

Além do artigo supracitado e transcrito, de acordo com Alexandre Mazza. (2015) outros dispositivos constitucionais também fazem referência ao dever de probidade administrativa, quais sejam: artigo 14, § 9.'; artigo $15, \mathrm{~V}$ e artigo $85, \mathrm{~V}$.

No que tange, à defesa constitucional da moralidade, a Carta Magna estabeleceu dois mecanismos processuais principais de natureza de garantias fundamentais, quais sejam: a) a ação popular - baseada constitucionalmente no artigo $5^{\circ}$, LXXIII da Constituição Federal; e b) a ação de improbidade administrativa - fundamentada no artigo $37, \S 4 .^{\circ}$ da Constituição Federal.

\section{COMPETÊNCIA PARA LEGISLAR SOBRE IMPROBIDADE ADMINISTRATIVA}

Se analisarmos o texto constitucional, não há clareza quanto ao ente competente para editar leis que tratem das punições para as condutas ímprobas.

O artigo 37 em seu $§ 4 .^{\circ}$ diz que os atos de improbidade gerarão: a) a suspensão dos direitos políticos; b) a perda da função pública; c) a indisponibilidade dos bens e d) ressarcimento ao erário na forma e gradação previstas em lei.

Com essa menção de "na forma e gradação previstas em lei" a Carta Magna deixa margem para o questionamento quanto à natureza das penas.

Para alguns administrativistas, como a professora Licínia Rossi (2015), a competência é diversa, ou seja, a natureza das sanções fixadas pela lei de improbidade pode ser: natureza política (aquela privativa da 
União - conforme artigo 22, I, da Constituição - por importar suspensão dos direitos políticos), civil (quando se referir à indisponibilidade de bens e à ressarcimento de danos ao erário) ou político- penal (conquanto gere perda da função pública).

Para outros, como o professor Alexandre Mazza. (2015), a competência legislativa é privativa da União.

No que tange a competência para processar e julgar ato de improbidade administrativa, de acordo com o informativo 546 do STJ,

(...) o simples fato de verba federal ter sido transferida da União, mediante convenio, para implementação de política pública em Município não afasta a competência da Justiça Federal para processar e julgar suposto ato de improbidade decorrente do desvio da referida quantia.

Ainda de acordo com o informativo 559 do STJ,

(...) compete à justiça estadual e não à justiça federal processar e julgar ação civil pública de improbidade administrativa na qual se apure irregularidades na prestação de contas, por ex-prefeito, relacionadas a verbas federais transferidas mediante convenio e incorporadas ao patrimônio municipal, a não ser que exista manifestação de interesse na causa por parte da União, de autarquia ou empresa pública federal.

\section{SUJEITOS DO ATO DE IMPROBIDADE}

O sujeito passivo do ato de improbidade é a entidade vítima, aquela que sofre os efeitos da conduta desonesta. A lei de improbidade administrativa fixa duas categorias de sujeito passivo, quais sejam: a) sujeitos passivos principais e b) sujeitos passivos secundários.

Os sujeitos passivos principais são aqueles que se encontram mencionados no artigo $1 .^{\circ}$ da Lei n. ${ }^{\circ} 8.429 / 92$, quais sejam: administração direta; administração indireta; pessoas para cuja criação ou custeio o erário haja contribuído ou contribua com mais de cinquenta por cento do patrimônio ou receita anual e empresa incorporado ao patrimônio público, ou seja, a Lei de Improbidade Administrativa, é aplicável aos atos praticados 
por qualquer agente público, servidor ou não, contra a administração direta, indireta ou fundacional de qualquer dos Poderes da União, dos Estados, do Distrito Federal, dos Munícipios, de Território, tendo, portanto, natureza jurídica de lei nacional.

Vale ressaltar que a legitimidade ativa para a propositura da ação de improbidade é concorrente entre as entidades citadas acima e o Ministério Público.

Os sujeitos passivos secundários, por sua vez, são as entidades que recebem subvenção, benefício ou incentivo fiscal ou creditício de órgão público e as entidades para cuja criação ou custeio o erário haja concorrido ou concorra com menos de cinquenta por cento do patrimônio ou receita anual.

Em relação à ótica municipal, os sujeitos passivos podem ser além do município, a autarquia ou a fundação pública municipal (pessoas jurídicas de direito público interno) ou as pessoas jurídicas municipais de direito privado (que são empresas públicas municipais, sociedade de economia mista municipal ou qualquer empresa pública que envolva capitais públicos).

Waldo Fazzio Júnior (2001, p. 57) diz que:

(...) os pacientes da improbidade administrativa municipal como qualquer entidade pública ou particular municipal que possua participação de dinheiro do município em seu patrimônio ou em sua receita anual, bem como a União, o Estado e suas entidades autárquicas e fundacionais, e, bem assim, paraestatais, quando o prefeito comete ato de improbidade contra seus bens e interesses alocados no Município ou que estejam sob a guarda deste.

Por outro lado, são considerados sujeitos ativos dos atos ímprobos: o agente público; o terceiro (aquele que, mesmo não sendo agente público, induz ou concorre para a prática do ato ou dele se beneficie de alguma forma) e o sucessor (essa responsabilidade é limitada ao valor da herança conforme artigos $8 .^{\circ}$ da Lei n. ${ }^{\circ} 8.429 / 92$; artigo 943 do Código Civil e 5. ${ }^{\circ}$, XLV, da Constituição Federal).

Assim, descreve Hely Lopes Meirelles (2002, p. 75) que 
(...) agentes públicos são todas as pessoas físicas incumbidas, definitiva ou transitoriamente, do exercício de alguma função estatal. $\mathrm{O}$ gênero agente público compreende os agentes políticos, administrativos, honoríficos, delegados e credenciados.

Da mesma forma, explica Celso Antônio Bandeira de Mello (2010, p. 244): Esta expressão - agentes públicos - é a mais ampla que se pode conceber para designar genérica e indistintamente os sujeitos que servem ao Poder Público como instrumentos expressivos de sua vontade ou ação, ainda quando o façam apenas ocasional ou episodicamente.

Completa José dos Santos Carvalho Filho (2010, p. 20) que:

Os agentes são o elemento físico da Administração Pública. [...] Agentes públicos são todos aqueles que, a qualquer título, executam uma função pública como preposto do Estado. São integrantes dos órgãos públicos, cuja vontade é imputada à pessoa jurídica. Compõem, portanto, a trilogia fundamental que dá o perfil da Administração: órgãos, agentes e funções.

Às luzes do trabalho, o sujeito ativo poderá ser prefeito e com ele podem colaborar agentes públicos ou terceiros estranhos à atividade administrativa. De acordo com o professor Matheus Carvalho (2016, p. 937), "além dos agentes públicos, particulares também podem responder por improbidade desde que se beneficiem ou concorram para a prática do ato."

Nesse sentido:

ADMINISTRATIVO. AGRAVO DE INSTRUMENTO. AÇÃO CIVIL PÚBLICA DE IMPROBIDADE ADMINISTRATIVA. PEDIDO DE INDISPONIBILIDADE DE BENS. ARTIGO 37, PARÁGRAFO $4 .^{\circ}$ DA CF/88. LEI 8.429/92. APLICABILIDADE AOS AGENTES POLÍTICOS. COMPETÊNCIA DA JUSTIÇA FEDERAL. I. Compete à Justiça Federal processar e julgar ação civil pública por ato de improbidade administrativa que envolva recursos federais, já que o dever de prestar contas deve ser cumprido junto a órgão federal, nos termos da súmula 208 do STJ. II. A decisão proferida pelo Supremo Tribunal Federal, nos autos da Reclamação no 2.138-6, 
conforme informativo $\mathrm{n}^{\mathrm{o}} 4$ do STF, não produz eficácia erga omnes nem efeito vinculante, sendo aplicada a agente político previsto no art. 102, I, c da CF/88. Aplica-se, portanto, ao Prefeito Municipal a Lei de Improbidade Administrativa. III. Constando nos autos documentos que indicam a prática de atos de improbidade, há de se determinar a indisponibilidade dos bens do agravado, no limite do possível prejuízo causado ao erário, posto que fundamentada no artigo 37, parágrafo $4 .^{\circ}$ da $\mathrm{CF} / 88$ e nos artigos $7 .^{\circ}$ e 16 da Lei ${ }^{\circ} 8.429 / 92$. IV. Não se trata de confisco a indisponibilidade dos bens prevista na Lei $\mathrm{n}^{\circ}$ 8.429/92, uma vez que, não prosperando a ação, os bens serão liberados. É medida acautelatória que visa garantir a reposição ao erário de possível lesão decorrente de atos de improbidade. V. AGRAVO DE INSTRUMENTO IMPROVIDO.(TRF-5 - AGTR: 94422 CE 0007212-81.2009.4.05.0000, Relator: Desembargadora Federal Margarida Cantarelli, Data de Julgamento: 28/07/2009, Quarta Turma, Data de Publicação: Fonte: Diário da Justiça - Data: 12/08/2009 - Página: 216 - $\mathrm{N}^{\mathrm{o}}$ : 153 - Ano: 2009).

Ademais, de acordo com o informativo 535 do STJ, "não é possível o ajuizamento de ação de improbidade administrativa exclusivamente em face de particular, sem a concomitante presença de agente público no polo passivo da demanda".

Importante esclarecer que houve uma decisão do Supremo Tribunal Federal que excluiu da abrangência da lei em estudo os agentes políticos, dizendo que os agentes políticos que respondem por crime de responsabilidade, nos moldes previstos na Carta Magna, não estão sujeitos à Lei de Improbidade porque o crime de responsabilidade estipula sanções de natureza civil e seria bis in idem admitir as duas punições.

Em que pese tal entendimento, o Superior Tribunal de Justiça nas reclamações 2790 e 2115 já se posicionou no sentido de que não há norma que pró́ba que os agentes políticos respondam por crimes de responsabilidade e por atos de improbidade. 
A norma constitucional do artigo 37, §4..$^{\circ}$ fixa uma relação mínima de penalidades, cabendo à norma infraconstitucional ampliar o rol das sanções conforme se inferem da análise os incisos do artigo 12 da LIA.

De acordo com Alexandre Mazza (2015), pode-se dizer que a Lei de Improbidade definiu contornos concretos para o princípio da moralidade administrativa.

Nos dizeres de Almeida Prado (2001), o dever de probidade está incorporado constitucionalmente no comportamento do administrador público sendo elemento fundamental para a legitimação de seus atos. Desse modo, o ato ímprobo do administrador público será punido com sanções políticas, administrativas e penais, na forma e gradação previstas em lei.

A aplicação das penalidades previstas na LIA será possível conquanto a decisão tenha transitado em julgado, vez ser garantido, em nosso ordenamento, o princípio constitucional de presunção de inocência (previsto no inciso LVII do art. 5..$^{\circ}$ da Constituição Federal), conforme artigo 20 da referida lei sendo permitido apenas - antes do trânsito em julgado o afastamento cautelar do agente nos termos do parágrafo único do artigo 20 da LIA.

Para que, de fato, sejam fixadas penalidades faz-se mister a observância dos seguintes princípios: da subsunção; da proporcionalidade e razoabilidade; da adequação punitiva e da independência das instâncias.

Cumpre salientar que, conforme posicionamento do Superior Tribunal de Justiça, não é possível que a sanção se limite - unicamente -ao ressarcimento de danos (essa ação de ressarcimento é imprescritível de acordo com artigo 37, §5. da Constituição Federal), afinal, dessa forma, apenas se voltaria, se recomporia o status quo. Por outro lado, no Resp. 1.245.622, o Superior Tribunal de Justiça entendeu que a LIA não deve ser aplicada para punir meras irregularidades administrativas, erros toleráveis ou transgressões disciplinares.

De modo genérico, aplicam-se aos casos de improbidade as seguintes sanções:

Perda da função pública - com essa sanção, o prefeito perde imediatamente o direito de cumprir seu mandato. Assim há a perda da investidura, podendo, sem prejuízo da remuneração, ser o prefeito afastado cautelarmente se necessário à instrução probatória de acordo com o que nos ensina o parágrafo único do artigo 20 da Lei de Improbidade. Findo o prazo que ensejou tal perda, nada impede que, se eleito novamente, volte o condenado a ser prefeito; 
Suspensão dos direitos públicos, variando a depender do ato ímprobo praticado - conforme se infere da análise do artigo 15, V, da Constituição Federal os direitos políticos são passíveis de suspensão e não de cassação, ou seja, admite-se a privação temporária da cidadania. Assim o prefeito que incorrer em improbidade administrativa não poderá: exercer capacidade eleitoral ativa e passiva; exercer direito à iniciativa popular de lei; promover ação popular; organizar ou participar de partido político; ser editor ou redator de órgão de imprensa e exercer cargo em sindicato. Tais direitos serão restabelecidos juntamente com a cidadania, quando findo o prazo determinado judicialmente;

Multa civil - trata-se de sanção pecuniária, (graduada conforme o ato) paga pelo agente público condenado à vítima da improbidade, tendo natureza não indenizatória, mas sim punitiva;

Interdição contratual - nesse caso, segundo Waldo Fazzio Júnior (2001, p. 145), "traz-se à tona a necessidade de haver a desconsideração da personalidade jurídica, posto que esta poderia servir de instrumento para burlar o impedimento de contratar, aplicado ao sócio ímprobo por sentença transitada em julgado".

Pode haver também a indisponibilidade de bens que é uma restituição daquilo que o agente público tenha auferido indevidamente; é uma garantia dada pela Carta Magna como medida cautelar. No que tange esse assunto, vale analisar o informativo 539 do STJ que diz: "os valores investidos em aplicações financeiras cuja origem remonte a verbas trabalhistas não podem ser objeto de medida de indisponibilidade em sede de ação de improbidade administrativa". Assim, é penhorável o rendimento da aplicação diferentemente do capital investido que tem natureza salarial.

Quanto à prescrição - nos termos do artigo 23 da LIA - é de 05 anos o prazo para o exercício do direito de ação contra agente público eleito, contando-se a partir do fim do mandato e o mesmo no que diz respeito ao terceiro beneficiado. Conforme dito acima, no caso de ressarcimento de danos, a ação é imprescritível.

Nos dizeres do informativo 546 do STJ, "nas ações civis por ato de improbidade administrativa, interrompe-se a prescrição da pretensão condenatória com o mero ajuizamento da ação dentro do prazo de cinco anos contado a partir do término do exercício do mandato, de cargo em comissão ou de função de confiança, ainda que a citação do réu seja efetivada após esse prazo." 
De acordo com posicionamento do Superior Tribunal de Justiça (Resp. 1.014.161), é punível a tentativa de improbidade nos casos em que as condutas não se realizam por motivos alheios à vontade do agente.

Quanto à condenação por danos morais na ação de improbidade, existe controvérsia jurisprudencial vez que a primeira turma rejeita, (Resp. 821.891) baseada na ideia de que o dano moral é caracterizado por dor, sofrimento psíquico e natureza transindividual. Por outro lado, a 2. ${ }^{\text {aTurma }}$ (Resp. 960.926) aceita vez que, para eles, o dano moral se caracteriza quer pela frustração causada pelo ato ímprobo à comunidade quer pelo desprestígio efetivo causado à entidade pública lesada.

Por fim, vale lembrar que as sanções da LIA são de natureza civil, política e administrativa, podendo haver concomitância de sua aplicação com as sanções penais em respeito ao princípio da independência das instâncias previsto, principalmente, no artigo 125 da Lei n. ${ }^{\circ}$ 8.112/90. A esse respeito há apenas uma exceção que é tratada no artigo 126 da Lei n. ${ }^{\circ} 8.112 / 90$ em que prevalece a decisão criminal sobre as demais esferas.

\section{CONCLUSÃO}

A Lei de Improbidade Administrativa surgiu em nosso ordenamento jurídico com escopo de regulamentar o $\S 4 .^{\circ}$ do art. 37 da Constituição Federal de 1988, cuja finalidade principal é a reparação dos danos causados pelo ato ímprobo, entendido como aquele que atente contra os princípios da moralidade administrativa e legalidade. E para se desincumbir de seu ônus, a referida lei estabeleceu sanções cíveis, políticas e administrativas a serem aplicadas ao agente ímprobo, bem como o responsabilizou pela reparação civil dos danos causados à Administração Pública por sua conduta.

O que pode se extrair da análise da jurisprudência, é que existe ainda certa oscilação quanto à natureza jurídica da Lei $\mathrm{n}^{\circ}$. 8.429/92, ora se atribuindo natureza penal à referida lei, ora a confundindo com o crime de responsabilidade.

Contudo, verifica-se que a doutrina e a jurisprudência dos Tribunais de Justiça e Tribunais Regionais Federais são praticamente uníssonas em manifestar-se pela natureza cível da Lei de Improbidade Administrativa, repudiando o entendimento da não aplicabilidade deste diploma legal aos agentes políticos. 
De fato, o manejo irresponsável das ações civis por improbidade administrativa é causa de enormes prejuízos à sociedade, seja quando proposta em face de servidores públicos seja em face de agentes políticos.

Todavia, deve-se observar que o legislador, atento para tal fato, disciplinou um procedimento especial para tais ações, prevendo um juízo prévio de admissibilidade, no qual é facultado ao demandado intervir, dificultando a propositura de ações movidas por razões alheias ao interesse público.

É importante ainda salientar que a ação civil por improbidade administrativa tem se revelado como um instrumento eficaz no controle da moralidade pública e na responsabilização do agente ímprobo.

Destarte, entender pela inaplicabilidade da Lei de Improbidade Administrativa aos agentes políticos é estimular o sentimento de impunidade que vigora em alguns setores da Administração Pública, o que somente colaborará com o descrédito das instituições estatais perante os cidadãos.

\section{REFERÊNCIAS}

ALMEIDA PRADO, Francisco Octávio. Improbidade administrativa. São Paulo: Malheiros, 2001.

ANJOS NETO, Fernando Chaves dos. Princípio da probidade administrativa: regime igualitário no julgamento dos agentes políticos. Belo Horizonte: Del Rey, 2003.

BRASIL. Constituição Federal. Brasília: Senado, 1988.

. Decreto-Lei n. ${ }^{\circ} 2.848$. Brasília: Senado, 1940.

.Lei n. ${ }^{\circ}$ 8.429. Lei de Improbidade Administrativa. Brasília: Senado, 1992.

Supremo Tribunal Federal. ADI n 2.797. Plenário. Rel.: Min. Sepúlveda Pertence. DJ 15.09.2005.

Supremo Tribunal Federal. Questão de Ordem em Petição n ${ }^{3.923-}$ 8. Plenário. Rel.: Min. Joaquim Barbosa. DJ 25.09.08

Superior Tribunal de Justiça. Reclamação n ${ }^{\circ}$ 591. SP. Corte Especial. Rel.: Min. Nilson Naves. DJ 01.12.1998.

CARVALHO, Rosimayre Gonçalves de. A ação de improbidade administrativa e os agentes políticos. Revista do Tribunal Regional Federal da $1^{a}$ Região, p. 27-38, v.19, n.4, abr. 2007.

CARVALHO FILHO, José dos Santos. Manual de direito administrativo. 22. ed. Rio de Janeiro: Lumen Juris, 2009. 
CARVALHO, Matheus. Manual de direito administrativo. 3. ed. Salvador: JusPodivim, 2016.

DELGADO. José Augusto. Improbidade administrativa: algumas controvérsias doutrinárias e jurisprudenciais sobre a lei de improbidade administrativa. BDJur, Brasília, DF. 2007. Disponível em: <http://bdjur.stj.gov.br/dspace/handle/2011/9555>. Acesso em: 16. Jun. 2015. DIREITO, Carlos Alberto Menezes. A disciplina jurídica do Impeachment. BDJur, Brasília, DF. 2006. Disponível em: <http://bdjur.stj.gov.br/dspace/handle/2011/9109>. Acesso em: 16. Jun. 2015.

DI PIETRO, Maria Sylvia Zanella. Direito administrativo. 20. ed. São Paulo: Atlas, 2007.

FAZZIO JÚNIOR, Waldo. Improbidade administrativa e crimes de prefeitos. São Paulo: Atlas, 2000.

FIGUEIREDO, Marcelo. Ação de improbidade administrativa, suas peculiaridades e inovações. In: BUENO, Cássio Scarpinella; REZENDE, Pedro Paulo de (Coord.). Improbidade administrativa: questões polêmicas e atuais. 2. ed. São Paulo: Malheiros, 2003.

.Probidade administrativa: comentários à Lei 8.429/92. 2. ed. São Paulo: Malheiros, 1997.

MACIEL, Adhemar Ferreira. Dimensões do direito público. Belo Horizonte: Del Rey, 2000.

MARTINS JÚNIOR, Wallace Paiva. Probidade administrativa. 3. ed. São Paulo: Saraiva, 2006.

MAZZA, Alexandre. Manual de direito administrativo. 5. ed. São Paulo: Saraiva, 2015.

MEIRELLES, Hely Lopes. Direito administrativo brasileiro. 27. ed. São Paulo: Malheiros, 2002.

MEIRA, José de Castro. Agentes públicos, agentes políticos. BDJur, Brasília, DF. 2008. Disponível em: <http://bdjur.stj.gov.br/dspace/handle/2011/16572>. Acesso em: 16. Jun. 2015.

MELLO, Celso Antônio Bandeira de. Curso de direito administrativo. 17. ed. São Paulo: Malheiros, 2004.

MIRANDA, Avay. Modificações introduzidas no processo de impeachment pela atual Constituição. Revista de Doutrina e Jurisprudência. Brasília. v. 40. p. 4858. set./dez. 1992.

PAZZAGLINI FILHO, Marino. Lei de improbidade administrativa comentada: aspectos constitucionais, administrativos, civis, criminais, processuais e de responsabilidade fiscal; legislação e jurisprudência atualizadas. 3. ed. São Paulo: Atlas, 2006.

RABELO, Manoel Alves; FACHETTI, Gilberto. A inexistência de fungibilidade entre a ação civil de improbidade administrativa (Lei 8.429/92) e a ação civil pública (Lei 7.347/85). Revista de Processo. ano 32. n 153. p. 47-64. nov/2007. 
RODRIGUES, Maria Rafaela Junqueira Bruno. Impeachment. Revista Jurídica da Universidade de Franca, Franca, v. 2, n. 2, p. 132-141, 1999.

VARGAS, Darlã Martins. A improbidade administrativa, o "bis in idem" com matéria penal e seus "tipos abertos". Revista Ibero-Americana de Direito Público.n 24. p 72-82. abril/junho, 2007.

ROSA, Márcio Fernando Elias. Corrupção como entrave ao desenvolvimento. Jus Navigandi, Teresina, ano 8, n. 229, 22. Fevereiro de 2004. Disponível em: <http://jus2.uol.com.br/texto.aspiid=4870>. Acesso em 15. fev. 2016.

ROSSI, Licínia. Manual de direito administrativo. 1. ed. São Paulo: Saraiva, 2015. SARMENTO, George. Improbidade administrativa. Porto Alegre: Síntese, 2002.

WALD, Arnoldo; MENDES, Gilmar Ferreira. Competência para julgar ação de improbidade administrativa. Revista de Informação Legislativa. Brasília. ano 35. n 138. p 213-216. abr/ jun 1998 